\title{
Four Cases of Desquamative Esophagitis Occurring after Hematopoietic Stem Cell Transplantation
}

\author{
Masaya Iwamuro ${ }^{1}$, Daisuke Ennishi ${ }^{2}$, Ken-ichi Matsuoka ${ }^{2}$, Takehiro Tanaka ${ }^{3}$, \\ Shotaro Okanoue ${ }^{1}$, Yuka Obayashi ${ }^{1}$, Hiroyuki Sakae ${ }^{1}$, \\ Yoshiro Kawahara $^{4}$ and Hiroyuki Okada ${ }^{1}$
}

\begin{abstract}
:
We herein report four patients with desquamative esophagitis that developed one to nine days after peripheral blood stem cell transplantation (PBSCT). Three patients underwent allogeneic PBSCT for leukemia, and the other underwent autologous PBSCT for pineoblastoma. Esophagogastroduodenoscopy revealed mucosal sloughing and fresh blood in the esophagus. Fasting and intravenous proton pump inhibitor therapy in addition to blood transfusion improved the esophageal lesions within five to seven days in three patients. These cases indicate that desquamative esophagitis can occur in patients who receive hematopoietic stem cell transplantation. Although blood transfusions may be required, it can be resolved within seven days.
\end{abstract}

Key words: desquamative esophagitis, sloughing esophagitis, esophagitis dissecans superficialis, peripheral blood stem cell transplantation

(Intern Med 59: 3015-3022, 2020)

(DOI: 10.2169/internalmedicine.4977-20)

\section{Introduction}

Desquamative esophagitis, also known as sloughing esophagitis or esophagitis dissecans superficialis, is a benign condition characterized by sheets of sloughed squamous tissue in the esophagus (1-3). While a rare disorder, cases of desquamative esophagitis have been reported to be associated with skin diseases (e.g., pemphigus vulgaris and lichen planus), medication intake (e.g., bisphosphonates, nonsteroidal anti-inflammatory drugs, and direct oral anticoagulants), esophageal injury (e.g., hot beverages, endoscopic dilatation, and sclerotherapy), and underlying esophageal disorders (e.g., eosinophilic esophagitis) (4-10). In contrast, few cases of desquamative esophagitis occurring after stem cell transplantation have been reported (11-13).

We herein report four cases of desquamative esophagitis that developed after peripheral blood stem cell transplanta- tion (PBSCT). Of note, although the esophageal mucosa sloughing remained unchanged in one patient despite treatment, esophagogastroduodenoscopy performed five to seven days later revealed the improvement of desquamative esophagitis in the other three patients.

\section{Case Reports}

The patient characteristics of the four cases of desquamative esophagitis after PBSCT are shown in Table 1. The medications used by the patients during the period from myeloablative conditioning therapy to the diagnosis of desquamative esophagitis are listed in Table 2.

\section{Case 1}

An 18-year-old Japanese woman underwent autologous PBSCT for refractory pineoblastoma. She received seven cycles of chemotherapy with ifosfamide, cisplatin, and

\footnotetext{
${ }^{1}$ Department of Gastroenterology and Hepatology, Okayama University Graduate School of Medicine, Dentistry, and Pharmaceutical Sciences, Japan, ${ }^{2}$ Department of Hematology and Oncology, Okayama University Graduate School of Medicine, Dentistry and Pharmaceutical Sciences, Japan, ${ }^{3}$ Department of Pathology, Okayama University Hospital, Japan and ${ }^{4}$ Department of Practical Gastrointestinal Endoscopy, Okayama University Hospital, Japan

Received: March 30, 2020; Accepted: June 22, 2020; Advance Publication by J-STAGE: August 4, 2020

Correspondence to Dr. Masaya Iwamuro, iwamuromasaya@yahoo.co.jp
} 
Table 1. Characteristics of Patients who Developed Desquamative Esophagitis after Hematopoietic Stem Cell Transplantation.

\begin{tabular}{|c|c|c|c|c|c|c|}
\hline Case & $\begin{array}{c}\text { Age } \\
\text { (years) }\end{array}$ & Sex & $\begin{array}{l}\text { Underlying } \\
\text { disease }\end{array}$ & SCT & $\begin{array}{l}\text { Days from SCT to } \\
\text { the diagnosis of DE }\end{array}$ & Outcome of DE \\
\hline 1 & 18 & $\mathrm{~F}$ & Pineoblastoma & Autologous PBSCT & 1 & $\begin{array}{l}\text { DE was healed on day } \\
7 \text { after the diagnosis }\end{array}$ \\
\hline 2 & 29 & M & $\begin{array}{l}\text { B-cell acute } \\
\text { lymphoblastic } \\
\text { leukemia }\end{array}$ & $\begin{array}{c}\text { Allogeneic PBSCT from } \\
\text { an HLA-haploidentical } \\
\text { related donor }\end{array}$ & 6 & $\begin{array}{l}\text { DE was healed on day } \\
7 \text { after the diagnosis }\end{array}$ \\
\hline 3 & 21 & M & $\begin{array}{c}\text { T-cell acute } \\
\text { lymphoblastic } \\
\text { leukemia }\end{array}$ & $\begin{array}{c}\text { Allogeneic PBSCT from } \\
\text { an HLA-haploidentical } \\
\text { related donor }\end{array}$ & 9 & $\begin{array}{l}\text { DE was healed on day } \\
5 \text { after the diagnosis }\end{array}$ \\
\hline 4 & 16 & M & $\begin{array}{c}\text { Acute myeloid } \\
\text { leukemia }\end{array}$ & $\begin{array}{l}\text { Allogeneic PBSCT from } \\
\text { an HLA-1-locus mis- } \\
\text { matched related donor }\end{array}$ & 5 & $\begin{array}{c}\text { DE persisted on day } 7 \\
\text { after the diagnosis }\end{array}$ \\
\hline
\end{tabular}

SCT: stem cell transplantation, DE: desquamative esophagitis, PBSCT: peripheral blood stem cell transplantation

Table 2. The Medications Used by the Patients During the Period from Myeloablative Conditioning Therapy to the Diagnosis of Desquamative Esophagitis.

\begin{tabular}{|c|c|c|c|c|c|c|}
\hline & Antacid & Antibiotic & Antiemetic & $\begin{array}{c}\text { Immunosuppressive } \\
\text { agent }\end{array}$ & $\begin{array}{c}\text { Chemotherapeutic } \\
\text { agent }\end{array}$ & Others \\
\hline 1 & $\begin{array}{c}\text { Esomeprazole, } \\
\text { lansoprazole }\end{array}$ & $\begin{array}{l}\text { Acyclovir, } \\
\text { cefepime, } \\
\text { doripenem, } \\
\text { fluconazole, } \\
\text { levofloxacin, } \\
\text { micafungin }\end{array}$ & $\begin{array}{l}\text { Aprepitant, } \\
\text { fosaprepitant, } \\
\text { granisetron, } \\
\text { metoclopramide, } \\
\text { prochlorperazine, } \\
\text { ramosetron }\end{array}$ & Hydrocortisone & $\begin{array}{c}\text { Cyclophosphamide, } \\
\text { melphalan, } \\
\text { nogitecan }\end{array}$ & $\begin{array}{l}\text { Acetaminophen, diphenhydramine, } \\
\text { famotidine, furosemide, glycyrrhizin, } \\
\text { haptoglobin, hydroxyzine, morphine, } \\
\text { sodium bicarbonate, ursodeoxycholic acid, } \\
\text { zonisamide }\end{array}$ \\
\hline 2 & $\begin{array}{l}\text { Lansoprazole, } \\
\text { omeprazole, } \\
\text { rabeprazole, } \\
\text { sodium } \\
\text { alginate }\end{array}$ & $\begin{array}{l}\text { Acyclovir, } \\
\text { fluconazole, } \\
\text { letermovir, } \\
\text { meropenem, } \\
\text { micafungin, } \\
\text { sulfamethoxazole/ } \\
\text { trimethoprim, } \\
\text { valacyclovir, } \\
\text { vancomycin, } \\
\text { voriconazole }\end{array}$ & $\begin{array}{l}\text { Aprepitant, } \\
\text { granisetron, } \\
\text { metoclopramide, } \\
\text { olanzapine }\end{array}$ & $\begin{array}{l}\text { Cyclophosphamide, } \\
\text { hydrocortisone, } \\
\text { mycophenolate } \\
\text { mofetil, tacrolimus }\end{array}$ & Fludarabine, mesna & $\begin{array}{l}\text { Acetaminophen, calcium gluconate, } \\
\text { clostridium butyricum, dalteparin sodium, } \\
\text { d-chlorpheniramine, furosemide, } \\
\text { lenograstim, magnesium sulfate, potassium } \\
\text { chloride, potassium hydrogen phosphate, } \\
\text { sodium bicarbonate, ursodeoxycholic acid }\end{array}$ \\
\hline 3 & $\begin{array}{l}\text { Omeprazole, } \\
\text { vonoprazan }\end{array}$ & $\begin{array}{l}\text { Acyclovir, } \\
\text { cefepime, } \\
\text { letermovir, } \\
\text { levofloxacin, } \\
\text { meropenem, } \\
\text { micafungin, } \\
\text { pentamidine, } \\
\text { sulfamethoxazole/ } \\
\text { trimethoprim, } \\
\text { valacyclovir, } \\
\text { voriconazole }\end{array}$ & $\begin{array}{c}\text { Aprepitant, } \\
\text { granisetron, } \\
\text { prochlorperazine }\end{array}$ & $\begin{array}{l}\text { Cyclophosphamide, } \\
\text { dexamethasone, } \\
\text { hydrocortisone, } \\
\text { mycophenolate } \\
\text { mofetil, tacrolimus }\end{array}$ & $\begin{array}{l}\text { Fludarabine, } \\
\text { melphalan, mesna }\end{array}$ & $\begin{array}{l}\text { Acetaminophen, alfacalcidol, } \\
\text { carbazochrome, clostridium butyricum, } \\
\text { dalteparin sodium, d-chlorpheniramine, } \\
\text { filgrastim, furosemide, lenograstim, } \\
\text { levothyroxine, magnesium oxide, } \\
\text { magnesium sulfate, midodrine, morphine, } \\
\text { oxycodone, potassium chloride, potassium } \\
\text { hydrogen phosphate, ramelteon, sodium } \\
\text { bicarbonate, thiamazole, ursodeoxycholic } \\
\text { acid, zolpidem }\end{array}$ \\
\hline 4 & $\begin{array}{c}\text { Lansoprazole, } \\
\text { omeprazole, } \\
\text { vonoprazan }\end{array}$ & $\begin{array}{l}\text { Acyclovir, } \\
\text { caspofungin, } \\
\text { itraconazole, } \\
\text { letermovir, } \\
\text { levofloxacin, } \\
\text { meropenem, } \\
\text { pentamidine, } \\
\text { sulfamethoxazole/ } \\
\text { trimethoprim, } \\
\text { tazobactam/ } \\
\text { piperacillin, } \\
\text { teicoplanin, } \\
\text { valacyclovir, } \\
\text { vancomycin }\end{array}$ & $\begin{array}{l}\text { Aprepitant, } \\
\text { domperidone, } \\
\text { granisetron, } \\
\text { metoclopramide, } \\
\text { prochlorperazine }\end{array}$ & $\begin{array}{l}\text { dexamethasone, } \\
\text { hydrocortisone, } \\
\text { methotrexate, } \\
\text { tacrolimus }\end{array}$ & $\begin{array}{c}\text { Gemtuzumab } \\
\text { ozogamicin, } \\
\text { cyclophosphamide, } \\
\text { mesna }\end{array}$ & $\begin{array}{l}\text { Acetaminophen, brotizolam, } \\
\text { carbazochrome, clostridium butyricum, } \\
\text { dalteparin sodium, d-chlorpheniramine, } \\
\text { fentanyl, furosemide, haptoglobin, herbal } \\
\text { medicine Choreito, hydroxyzine, } \\
\text { lenograstim, loperamide, magnesium } \\
\text { sulfate, mosapride, nicardipine, potassium } \\
\text { chloride, sodium bicarbonate, tranexamic } \\
\text { acid, ursodeoxycholic acid }\end{array}$ \\
\hline
\end{tabular}




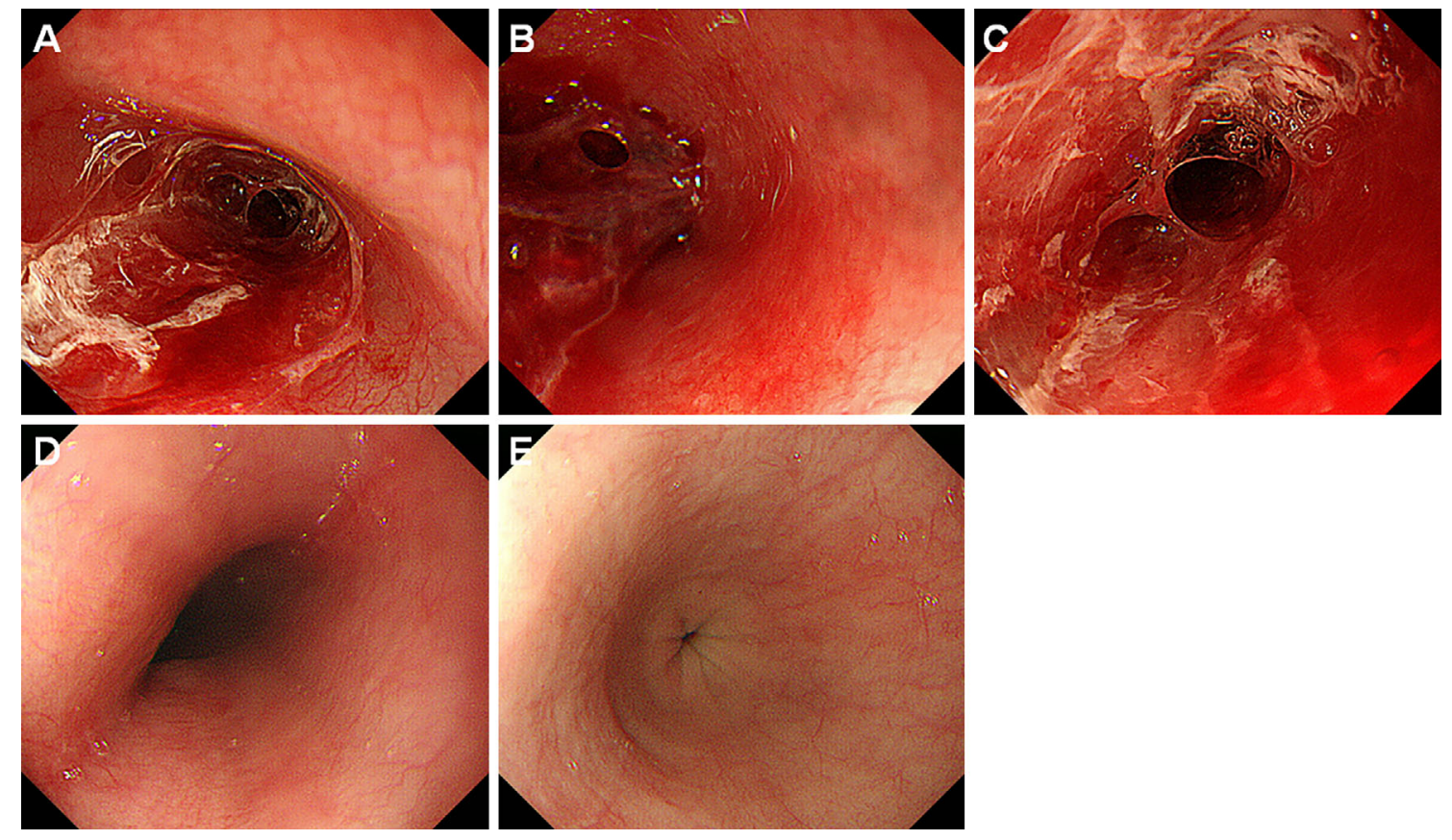

Figure 1. Endoscopic images of case 1. An 18-year-old woman developed desquamative esophagitis one day after PBSCT (A-C). She was treated with fasting, intravenous administration of lansoprazole, and red blood cell transfusion. Esophagogastroduodenoscopy performed seven days later showed improvement of the esophageal lesion (D, E). PBSCT: peripheral blood stem cell transplantation

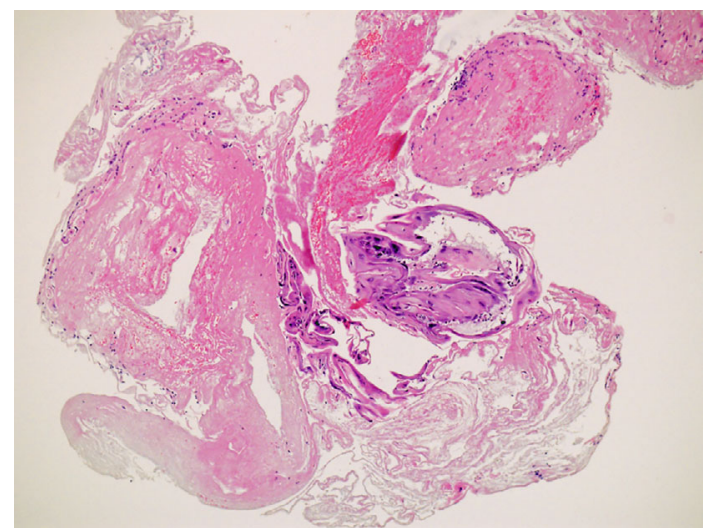

Figure 2. Pathological examination findings of case 1. The biopsy specimen from the sloughed esophageal mucosa revealed necrotic tissue and degenerative squamous cells.

etoposide before PBSCT. After conditioning with a myeloablative regimen consisting of topotecan, melphalan, and cyclophosphamide, seven days before PBSCT, the patient developed febrile neutropenia and was treated with cefepime followed by doripenem. The administration of acyclovir was also started seven days before PBSCT. On the day of PBSCT, she manifested oral mucositis and diarrhea, and morphine was administered. Since she vomited blood a day after undergoing PBSCT, we performed esophagogastroduodenoscopy, which revealed extensive sloughing of the esophageal mucosa and fresh blood (Fig. 1A-C). We therefore diagnosed her with desquamative esophagitis.

A histopathological examination of the esophageal mucosal biopsy samples revealed necrotic tissues and degenera- tive squamous cells (Fig. 2). Immunostaining for herpes simplex virus was negative. Concomitantly, her white blood cells were $40 / \mu \mathrm{L}$, hemoglobin was $6.5 \mathrm{~g} / \mathrm{dL}$, and platelets were $57,000 / \mu \mathrm{L}$. She was treated with fasting and intravenous lansoprazole along with red blood cell transfusions. Esophagogastroduodenoscopy performed seven days later showed a healed esophageal mucosa (Fig. 1D, E).

\section{Case 2}

A 29-year-old Japanese man underwent haploidentical PBSCT for B-cell acute lymphoblastic leukemia. Although the leukemia was initially treated with intensive induction polychemotherapy, remission was not achieved. Thus, the patient received two cycles of inotuzumab ozogamicin and subsequently underwent PBSCT. Myeloablative conditioning was performed with 12 Gy of total body irradiation and fludarabine. The administration of dalteparin sodium was started the day before PBSCT to prevent sinusoidal obstruction syndrome. Valacyclovir and letermovir administration was also initiated the day before and after PBSCT, respectively. After PBSCT, the patient received a two-day infusion of cyclophosphamide, followed by the administration of mycophenolate mofetil and tacrolimus. Six days after PBSCT, he developed melena and hematochezia. His white blood cell count was $20 / \mu \mathrm{L}$, hemoglobin level was $5.6 \mathrm{~g} / \mathrm{dL}$, and platelet count was 14,000/ $\mathrm{LL}$. Esophagogastroduodenoscopy showed a huge bloodlike lump in the middle to lower esophagus. In the middle part of the esophagus, the bloody mass occupied approximately half of the esophageal lumen and was also partly observed in the longitudinal border (Fig. 3A, arrows). In the esophagogastric junction, 

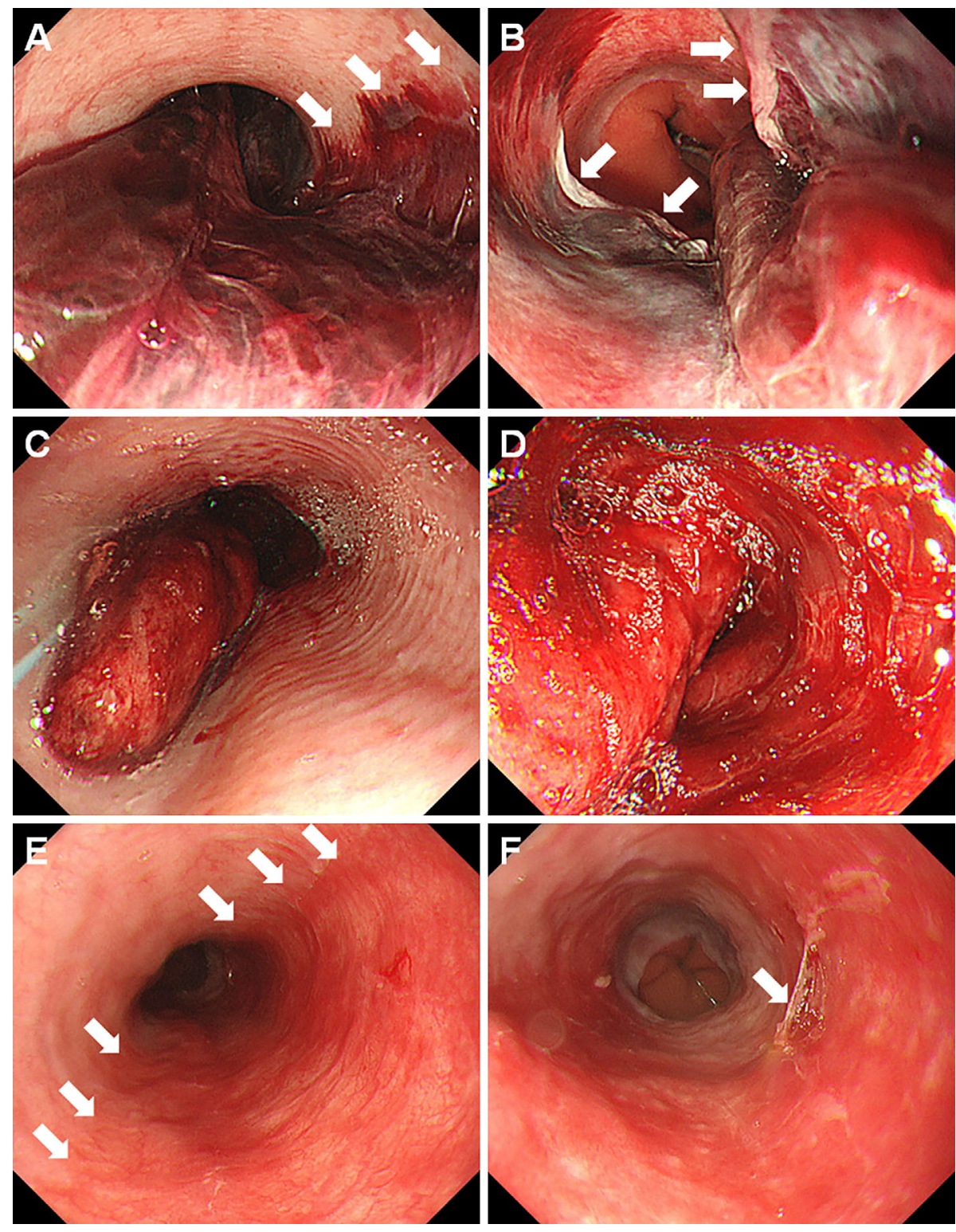

Figure 3. Endoscopic images of case 2. A 29-year-old man who underwent haploidentical PBSCT developed desquamative esophagitis on day $6(\mathrm{~A}, \mathrm{~B})$. A bloody mass was observed at the longitudinal border in the middle part of the esophagus (A, arrows), and squamous mucosa was found in the lower end of the lesion (B, arrows). Treatment with fasting, administration of omeprazole and sodium alginate, and red blood cell and platelet transfusion was initiated. However, the sloughed esophageal mucosa remained unchanged four days later $(C, D)$. Improvement of the esophageal lesions was confirmed by esophagogastroduodenoscopy performed seven days after the diagnosis $(E, F)$. Half of the mucosa of the middle esophagus was reddish, which we considered to be vestiges of the desquamated area (E, arrows). Damaged esophageal mucosa was also partly observed in the reddish area (F, arrow). PBSCT: peripheral blood stem cell transplantation

squamous mucosa was seen in the lower end of the lesion (Fig. 3B, arrows). We therefore suspected that a hematoma had formed after desquamation of the esophageal mucosa.

The patient was treated with fasting and intravenous omeprazole therapy, and per-oral sodium alginate. The administration of dalteparin sodium was stopped. Red blood cells and platelets were also transfused. Esophagogastroduodenoscopy performed four days after treatment showed persistence of mucosal sloughing, hematoma, and bleeding (Fig. 3C, D). Although the esophageal lesions mostly healed seven days after the diagnosis of desquamative esophagitis, half of the mucosa of the middle esophagus was reddish, which we considered to be vestiges of the desquamated area (Fig. 3E, arrows). Damaged esophageal mucosa was partly observed in the reddish area (Fig. 3F, arrow).

\section{Case 3}

A Japanese boy was diagnosed with T-cell acute lymphoblastic leukemia at 5 years of age and underwent haploidentical PBSCT at 7 years of age. However, the leukemia 


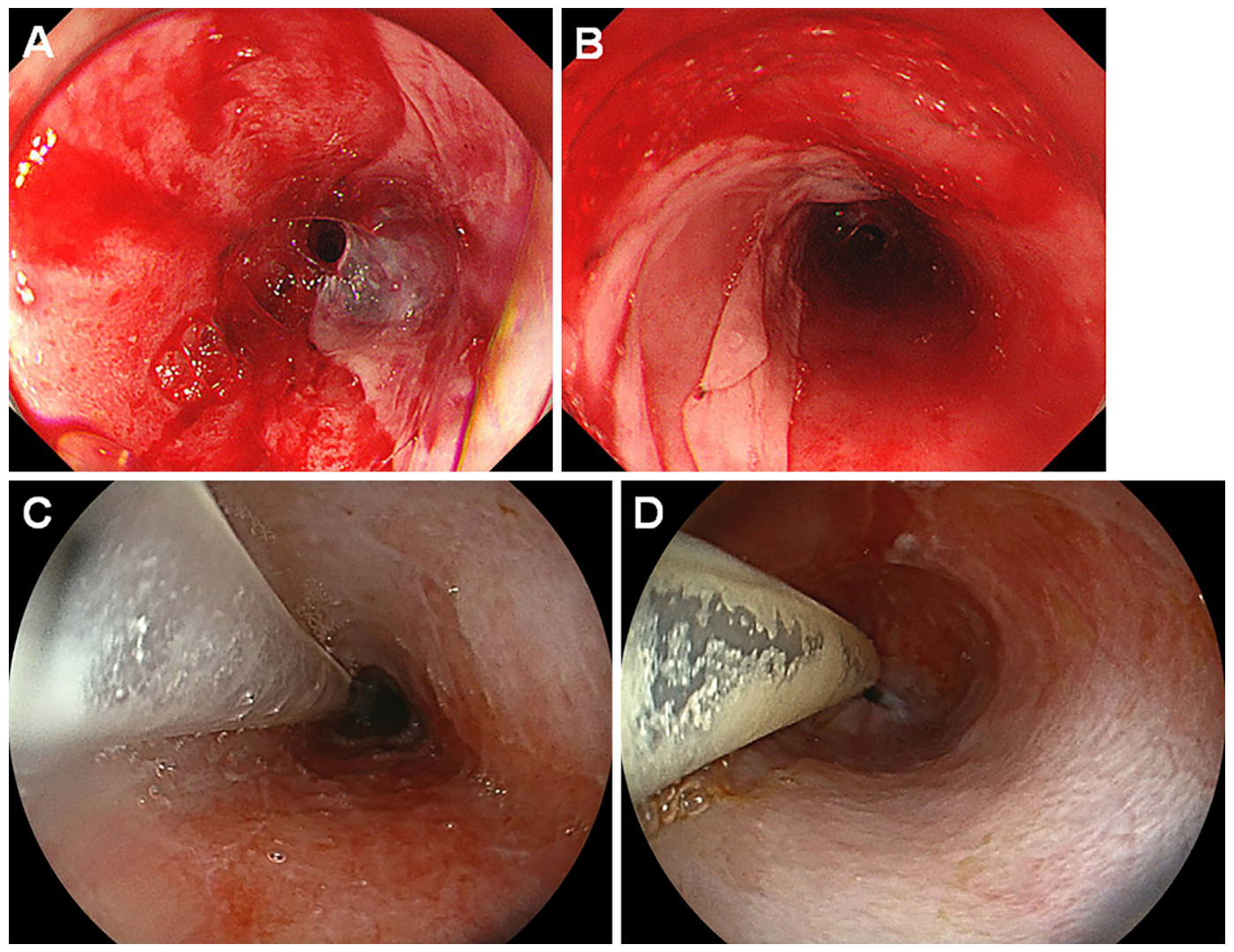

Figure 4. Endoscopic images of case 3. On day 9 after haploidentical PBSCT, a 21-year-old man developed desquamative esophagitis (A, B). Esophagogastroduodenoscopy performed five days later showed epithelialized esophageal mucosa (C, D). PBSCT: peripheral blood stem cell transplantation

recurred, and he received multiple chemotherapies. Thus, a second haploidentical PBSCT procedure was planned at 21 years of age. Myeloablative conditioning was performed with total body irradiation, fludarabine, and melphalan. Intravenous injection of dalteparin sodium was started six days before PBSCT to prevent sinusoidal obstruction syndrome. Valacyclovir and letermovir administrations were also initiated seven days before and on the day of PBSCT, respectively. After PBSCT, mycophenolate mofetil and tacrolimus were administered on day 5. On day 9, he developed hematemesis. Esophagogastroduodenoscopy results revealed fresh blood and peeled esophageal mucosa (Fig. 4A, B). Desquamative esophagitis was treated with fasting, intravenous omeprazole therapy, and discontinuation of dalteparin sodium. Since his white blood cell count was $30 / \mu \mathrm{L}$, hemoglobin was $8.9 \mathrm{~g} / \mathrm{dL}$, and platelet count was $24,000 / \mu \mathrm{L}$, platelet transfusion was performed. Esophagogastroduodenoscopy performed five days later showed epithelialized esophageal mucosa (Fig. 4C, D).

\section{Case 4}

A 15-year-old Japanese boy was diagnosed with acute myelomonocytic leukemia and received chemotherapy with daunorubicin and cytarabine, followed by consolidation and post-remission therapies. However, the leukemia recurred at 16 years of age. Salvage chemotherapy with fludarabine, cytarabine, and mitoxantrone failed, after which gemtuzumab ozogamicin was administered. Subsequently, he underwent allogeneic PBSCT from his human leukocyte antigen (HLA)-1-locus mismatched mother. Myeloablative conditioning was performed with total body irradiation and cyclophosphamide. Dalteparin sodium injection was administered once five days before PBSCT. Tacrolimus was administered a day before PBSCT, and methotrexate was administered on day 3 after PBSCT. Valacyclovir and letermovir administrations were also initiated seven days before and on the day of PBSCT, respectively. On day 5, the patient developed hematemesis, and esophagogastroduodenoscopy showed a bloody mass in the esophagus (Fig. 5A, B). Because the endoscopic images (Fig. 3C, D) and the patient's clinical course resembled that of case 2, we diagnosed the patient with desquamative esophagitis.

His white blood cell count was $10 / \mu \mathrm{L}$, hemoglobin was $9.1 \mathrm{~g} / \mathrm{dL}$, and platelet count was $14,000 / \mu \mathrm{L}$. Subsequently, red blood cells and platelets were transfused. Although the esophagitis was treated with fasting and intravenous omeprazole, esophagogastroduodenoscopy performed seven days after the diagnosis revealed that the clump of blood-like substance was unchanged (Fig. 5C). The lower end of the lesion was partly membranous (Fig. 5D, arrows), which we considered to be peeled-off esophageal mucosa. Because his systemic status had deteriorated, no additional endoscopy examinations were performed. 


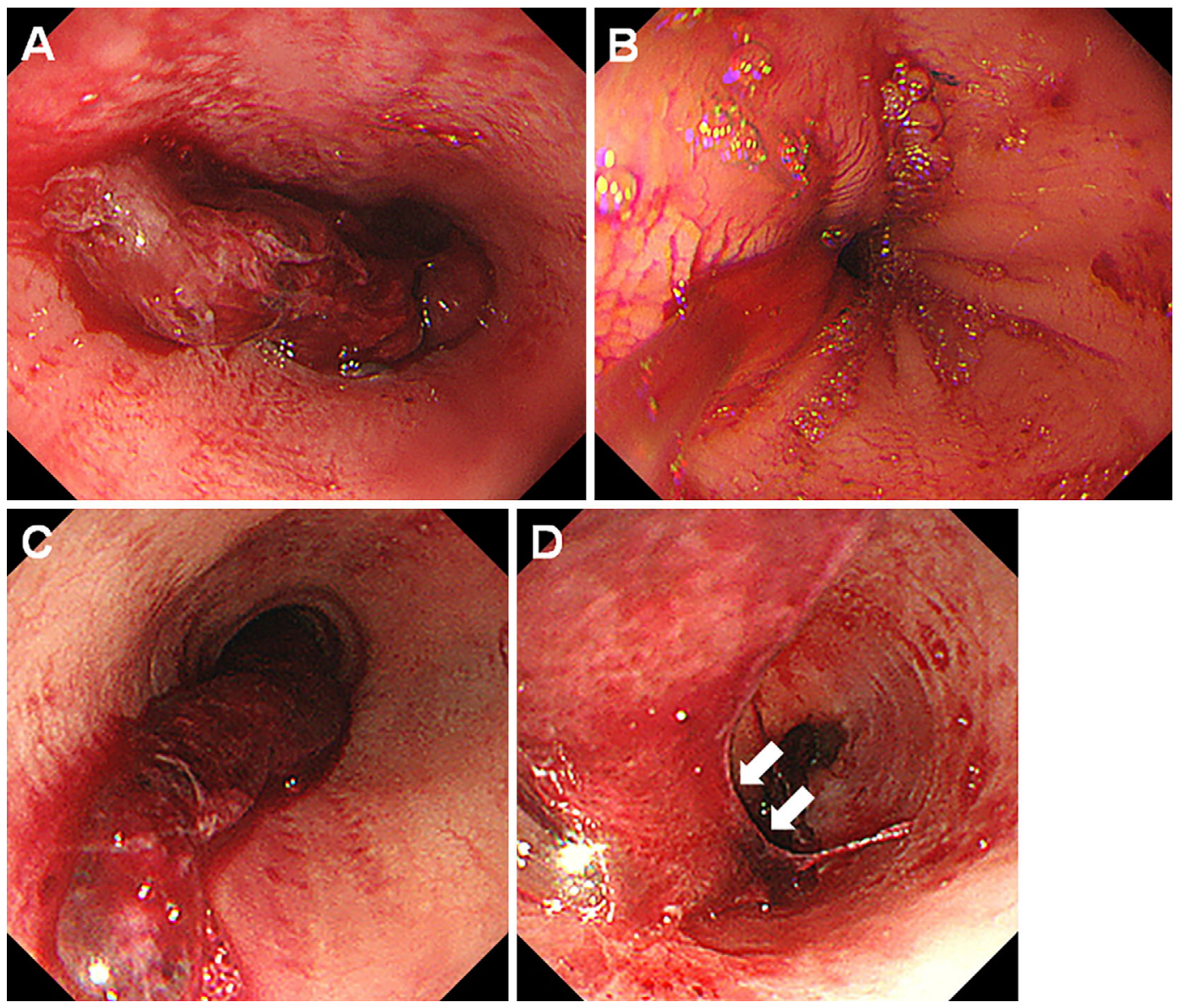

Figure 5. Endoscopic images of case 4. A 16-year-old boy who underwent HLA-1-locus mismatched PBSCT developed desquamative esophagitis on day 5 (A, B). Esophagogastroduodenoscopy performed seven days after the diagnosis revealed that the sloughed esophageal mucosa was unchanged (C, D). The lower end of the lesion was partly membranous (D, arrows), which we considered to be peeled-off esophageal mucosa. PBSCT: peripheral blood stem cell transplantation, HLA-1: human leucocyte antigen-1

\section{Discussion}

We herein present the reports of four cases of desquamative esophagitis that occurred one to nine days after PBSCT. McDonald et al. reported that, among 63 patients with chronic graft-versus-host disease who were examined after allogeneic bone marrow transplantation, 8 had esophageal involvement (13). Although an endoscopic examination was not performed in one patient, all other patients developed desquamative esophagitis. The mean duration until the esophageal symptom onset was 220 days after transplantation (range, 69-632 days). Other previous reports of desquamative esophagitis after hematopoietic stem cell transplantation have described it as a manifestation of chronic graftversus-host disease $(11,12)$. However, in our four patients, desquamative esophagitis was diagnosed within nine days after PBSCT, indicating that esophageal mucosal sloughing can occur in the acute phase in patients who undergo hematopoietic stem cell transplant.

The typical endoscopic appearance of desquamative esophagitis includes sheets of partially sloughed, crumpled, or detached mucosa and linear strips of desquamated mucosal layers (1-4). In the present study, all of the patients showed blood adhesion in the esophagus and sloughed mucosa. Thrombocytopenia after hematopoietic stem cell transplantation and dalteparin sodium therapy, which was continuously administered in cases 2 and 3, may have caused the bleeding from the desquamated esophageal wall, which resulted in hematemesis, melena, and/or hematochezia. In addition, a hematoma (Fig. 3A, B) and a clump of blood were observed in case 2 (Fig. 3C) and case 4 (Fig. 5A, C). We speculated that, as described above, hematoma formation had occurred beneath the desquamated esophageal mucosa. The clump of blood might have been composed of rolled up sloughed mucosa and blood. However, because we did not perform a pathological analysis of the hematoma or the clump of blood, the mechanisms underlying the occurrence of these lesions have not been elucidated.

Several hypotheses may be able to explain the pathogenesis of desquamative esophagitis in the present four patients: graft-versus-host disease, infection, radiation, intensive treatment sequences, and medication-induced mucosal damage. In general, the esophagus is infrequently affected by acute 
graft-versus-host disease. Furthermore, no patient manifested symptoms of acute graft-versus-host disease, such as skin rashes, diarrhea, or high levels of liver enzymes. However, an aggressive alloimmune reaction may have been involved in the development of desquamative esophagitis in cases 24 , as these patients underwent HLA-mismatched PBSCT.

Viruses, such as cytomegalovirus and herpes simplex virus, can affect the esophagus, particularly in immunocompromised critically ill patients. Patients in the acute phase after PBSCT are susceptible to viral infection even under prophylactic antibiotic treatment. Thus, although antiviral drugs had been administered to all our patients prior to PBSCT, viral infection may have induced esophageal damage. Radiation therapy also causes inflammation, edema, erythema, and erosion of the mucosal surface of the esophagus. Therefore, it may lead to desquamative esophagitis. Nevertheless, radiation-induced mucosal damage is unlikely to be the common etiology for desquamative esophagitis in our patients because case 1 did not undergo total body irradiation. Among those who underwent allogeneic transplant, all three were young and had recurrent/refractory leukemia; therefore, intensive pretransplant treatments and HLAmismatched PBSCTs with myeloablative conditioning were performed. Such intensive treatment sequences might have affected the esophageal tissue.

Other drugs administered before symptom onset could also be possible causes of medication-related toxicity and/or esophageal infection, which resulted in esophageal mucosal sloughing. Mycophenolate mofetil has been reported to induce gastrointestinal tract abnormalities, such as circumferential inflammation, ulcers, and esophageal stricture (14-16). However, only two patients received mycophenolate mofetil, whereas the other two did not take the drug. As shown in Table 2, the common drugs administered to all four patients were mesna, acyclovir, aprepitant, granisetron, cyclophosphamide, hydrocortisone, furosemide, sodium bicarbonate, and ursodeoxycholic acid. Some of these drugs are known to cause adverse gastrointestinal manifestations (17-19). Thus, one of these drugs or their combination might have caused the desquamative esophagitis in our patients. Further investigations will be required to determine the etiology of desquamative esophagitis that develops in the acute phase after PBSCT.

It is noteworthy that three of the four patients recovered from desquamative esophagitis within seven days of the diagnosis. Although the infusion of red blood cells and/or platelets was required for the treatment of anemia and thrombocytopenia, patients were treated with fasting and the intravenous administration of proton pump inhibitors. These results indicate that desquamative esophagitis occurring in the acute phase of PBSCT is only transient damage to the superficial esophageal mucosa and should be treated conservatively.

In conclusion, our patients developed desquamative esophagitis one to nine days after PBSCT. Fasting and intravenous administration of proton pump inhibitors in combi- nation with blood transfusion helped ameliorate the sloughed esophageal mucosa in three of the four patients. Although the exact pathogenesis is uncertain, we believe that understanding the unique manifestation and outcome of this esophageal lesion will help hematologists and gastroenterologists manage adverse events in patients undergoing hematopoietic stem cell transplantation.

The authors state that they have no Conflict of Interest (COI).

\section{References}

1. Akhondi H. Sloughing esophagitis: a not so common entity. Int J Biomed Sci 10: 282-286, 2014.

2. Purdy JK, Appelman HD, McKenna BJ. Sloughing esophagitis is associated with chronic debilitation and medications that injure the esophageal mucosa. Mod Pathol 25: 767-775, 2012.

3. Carmack SW, Vemulapalli R, Spechler SJ, Genta RM. Esophagitis dissecans superficialis ("sloughing esophagitis"): a clinicopathologic study of 12 cases. Am J Surg Pathol 33: 1789-1794, 2009.

4. Shah R, Thoguluva V, Bansal N, Manocha D. Esophageal dissecans: a rare life-threatening presentation of recurrent pemphigus vulgaris. Am J Emerg Med 33: e1-e2, 2015.

5. Ma H, Chen M, Liu J, Li Y, Li J. Serious stomatitis and esophagitis: a peculiar mucous reaction induced by pegylated liposomal doxorubicin. An Bras Dermatol 90: 209-211, 2015.

6. Shah SA, Cho M, Chaptini L, Parikh N. Sloughing esophagitis: an atypical cause of food impaction. ACG Case Rep J 3: e85, 2016.

7. Dumas-Campagna M, Bouchard S, Soucy G, Bouin M. IgG4related esophageal disease presenting as esophagitis dissecans superficialis with chronic strictures. J Clin Med Res 6: 295-298, 2014.

8. Hart PA, Romano RC, Moreira RK, Ravi K, Sweetser S. Esophagitis dissecans superficialis: clinical, endoscopic, and histologic features. Dig Dis Sci 60: 2049-2057, 2015.

9. Hokama A, Yamamoto Y, Taira K, et al. Esophagitis dissecans superficialis and autoimmune bullous dermatoses: a review. World J Gastrointest Endosc 2: 252-256, 2010.

10. Nidimusili AJ, Dhadam GC, Shaheen K. Sloughing esophageal mucosa. QJM 107: 77-78, 2014.

11. Trabulo D, Ferreira S, Lage P, Rego RL, Teixeira G, Pereira AD. Esophageal stenosis with sloughing esophagitis: a curious manifestation of graft-vs-host disease. World J Gastroenterol 21: 92179222, 2015.

12. Nakshabendi IM, Maldonado ME, Coppola D, Mamel JJ. Esophageal cast: a manifestation of graft-versus-host disease. Dig Dis 18: 103-105, 2000.

13. McDonald GB, Sullivan KM, Schuffler MD, Shulman HM, Thomas ED. Esophageal abnormalities in chronic graft-versus-host disease in humans. Gastroenterology 80: 914-921, 1981.

14. Matin T, Zhao Y, Goyal J, Weber F. Mycophenolate induced GI mucosal injury - case report and review of the literature. MOJ Clin Med Case Rep 8: 96-98, 2018.

15. Liu K, Kia L. Mycophenolate mofetil-induced esophagitis. Clin Gastroenterol Hepatol 17: e139, 2019.

16. Delacruz V, Weppler D, Island E, et al. Mycophenolate mofetilrelated gastrointestinal mucosal injury in multivisceral transplantation. Transplant Proc 42: 82-84, 2010.

17. Blijlevens NM. Cytotoxic treatment-induced gastrointestinal symptoms. Curr Opin Support Palliat Care 1: 16-22, 2007.

18. Liu $\mathrm{T}$, Wu Y, Wang $\mathrm{L}$, et al. A more robust gut microbiota in calorie-restricted mice is associated with attenuated intestinal injury caused by the chemotherapy drug cyclophosphamide. mBio 
10: e02903-e02918, 2019.

19. Xie JH, Fan ST, Nie SP, et al. Lactobacillus plantarum NCU116 attenuates cyclophosphamide-induced intestinal mucosal injury, metabolism and intestinal microbiota disorders in mice. Food Funct 7: 1584-1592, 2016.
The Internal Medicine is an Open Access journal distributed under the Creative Commons Attribution-NonCommercial-NoDerivatives 4.0 International License. To view the details of this license, please visit (https://creativecommons.org/licenses/ by-nc-nd/4.0/).

(C) 2020 The Japanese Society of Internal Medicine Intern Med 59: 3015-3022, 2020 